\title{
Spontaneous hybrids of Prunus fruticosa Pall. in Hungary
}

\author{
K. Hrotkó $\cdot$ Y. Feng • J. Halász
}

Received: 5 April 2019/Accepted: 21 October 2019/Published online: 31 October 2019

(C) The Author(s) 2019

\begin{abstract}
The European ground cherry (Prunus fruticosa Pall.) as a potential dwarfing rootstock attracted the attention of cherry rootstock researchers in several breeding projects. In order to clarify some doubtful classification of collected and promising specimen of supposed hybrids, we compared morphological characteristics to literature data. Genetic analysis was also undertaken using simple-sequence repeat markers. Our results suggest that the investigated $P$. fruticosa forma fruticosa specimens are tetraploid and the genetic analysis did not contribute to distinguish the $P$. fruticosa forma fruticosa and forma aucta. Based on morphological characters, we identified few specimens of spontaneous hybrid $P$. fruticosa $\times$ P. mahaleb $(P . \times$ jávorkae $)$. Our genetic analysis supports the hypothesis that the sample shrub is triploid and show genetic relationship with $P$.
\end{abstract}

\section{K. Hrotkó}

Department of Floriculture and Dendrology, Faculty of Horticultural Science, Szent István University, Villányi Str. 35-43, Budapest 1118, Hungary

Y. Feng

College of Horticulture, Northwest Agricultural and

Forestry University, No. 3 Taicheng Road,

Yangling 710021, Shaanxi, People's Republic of China

J. Halász ( $\square)$

Department of Genetics and Plant Breeding, Faculty of Horticultural Science, Szent István University, Ménesi

Str. 44, Budapest 1118, Hungary

e-mail: halasz.julia@kertk.szie.hu mahaleb. This triploid hybrid due to the flower sterility represents a blind alley in its evolution. We identified from each investigated habitat specimens of supposed hybrid derivatives of ground cherry $P$. fruticosa $\times P$. avium $(P . \times$ mohácsyana $)$. This hybrid clearly showed distinct morphological characteristics, easily distinguishable from the $P$. fruticosa f. fruticosa and $\mathrm{f}$. aucta and the genetic analysis suggests that the accessions are triploid. The flower sterility limits the usage of this hybrid derivative for further crossbreeding but allows usage as clonal cherry rootstock. Our genetic analysis suggests that samples of P. $\times$ eminens are tetraploid, fertile hybrid derivative of ground cherry occurring in some habitats of the basic species and show similar morphological characters to the cultivated sour cherry.

Keywords Hybrid derivatives - Morphology characterization · Ploidy level ·

Prunus $\times$ mohácsyana $\cdot$ Prunus $\times$ jávorkae.

Prunus $\times$ eminens

\section{Introduction}

The European ground cherry (syn. Mongolian cherry, Prunus fruticosa Pall.) is a short shrub (height 0.3-1.0 m) classified into Section 3, Eucerasus by Rehder (1990). It occurs in flatlands with dry steppe 
vegetation, or in hilly regions in thickets on dry karst areas often associated with Prunus avium L. and Prunus mahaleb L. The ground cherry is native to Europe, Western Siberia, and Western China (Xinjiang), with high winter hardiness (USDA Zone 2) for various agroforestry use (Terpó 1974; Krüssmann 1978; Rehder 1990; Dzhangaliev et al. 2003). As the shrub produces edible fruits, in certain countries in cold areas breeding projects targeted selection of varieties among hybrids for fruit production (Bors 2005). As a potential dwarfing rootstock the shrub attracted the attention of cherry rootstock researchers. The species and derivatives have been considered as rootstock for sweet and sour cherry in several breeding projects (Cummins 1972; Plock 1973; Hein 1979; Gruppe 1985; Hrotkó and Facsar 1996; De Palma et al. 1996; Eremin et al. 2000; Eremin and Eremin 2002; Hrotkó 2004; Rozpara and Grzyb 2004; Hrotkó et al. 2008; Magyar and Hrotkó 2008, 2013; Barać et al. 2013, 2017; Maas et al. 2014).

The ground cherry occurs in the Carpathian basin in specific habitats considered as relict from the steppe vegetation patches. It was first mentioned in the literature by Evlia Chelebi, a Turkish traveler in the seventeeenth century who described the strange, 0.4-0.5 m high cherry shrubs in the Buda Hills producing edible fruits (Surányi 1982). In several locations in Hungary the ground cherry occurs in thickets and open woodlands on dry slopes or on dry karst areas together with $P$. mahaleb (L.) and in neighboring forest areas $P$. avium (L.) Basic botany works describe $P$. fruticosa and their hybrids as rather divaricate species (Krüssmann 1978; Rehder 1990; Dzhangaliev et al. 2003) but do not make distinctions between $0.2-0.5 \mathrm{~m}$ high shrubs and the 1-2 $\mathrm{m}$ tall shrubs or even higher, $2-3 \mathrm{~m}$ high small trees. Recent studies by Barac et al. $(2013,2017)$ and Macková et al. (2017) confirmed this large morphological and genetic variability in Serbia and in Slovakia as well. In several sites in Hungary, the ground cherry shows large variability in phenotypic characters supposedly due to spontaneous hybridization but their taxonomic identification and classification by genetic tools is still missing.

In Central- and East-Europe the native geographic area of $P$. fruitcosa overlaps with $P$. avium and $P$. mahaleb, which in certain years allows spontaneous crosses (Kárpáti 1944; Terpó 1974; Wojcicki 1991a; Hrotkó and Facsar 1996; Faust and Surányi 1997). As a possible hybrid $P . \times$ eminens Beck $(P$. cerasus $\times P$. fruticosa) is first mentioned by Beck (1893), and later Krüssmann (1978) and Rehder (1990); described as upright shrub, 1-3 m high; leaves and flowers usually longer stalked, and somewhat larger than those of $P$. fruticosa, otherweise somewhat intermediate between the parents. Kárpáti (1944) found several habitats with specimens of similar hybrids but he disagreed with Beck's statement being no incidence of the female parent $P$. cerasus in the wide surroundings. Similar morphological traits to $P$. eminens are described by Wojcicki (1991a, b) for Prunus $\times$ stacei $(P$. fruticosa $\times P$. cerasus $\times P$. avium), which proved to be triploid $(2 n=3 x=24)$.

Hungarian botanists in the first half of last century noticed the diversity of $P$. fruticosa and classified them based on their phenotypic characteristics. Borbás (1900) divided the ground cherry population into $P$. fruticosa forma fruticosa (short, 0.3-0.6 $\mathrm{m}$ type, leaves are $2-3 \mathrm{~cm}$ ) and $P$. fruticosa forma aucta (Borb.) (tall type, $1.5-2.5 \mathrm{~m}$, leaves are larger, 4-6 cm). This classification was accepted and used by Kárpáti (1944) and Terpó (1974). Based on specimens found in herbarium and during field studies in Hungary, Kárpáti (1944) separated among the taller growing and large leaf types of $P$. fruticosa $\mathrm{f}$. aucta another hybrid group and named it $P . \times$ mohácsyana Kárp. ( $P$. avium $\times P$. fruticosa). Recently Macková et al. (2017) analysed the $P$. fruticosa populations and hybrids which provide more insights into the genetic structure and hybridization potentials of the species. By their analysis, $P . \times$ mohácsyana was triploid, while the $P$. eminens samples proved to be tetraploid. The triploid hybrids most probably do not participate in further backcrossing or further hybridization due to their flower sterility but tend to occupy niches and may overgrow lower $P$. fruticosa shrubs.

From among herbarium specimens of the Hungarian National Museum, identified earlier as P. fruticosa f. aucta (Borb.), another new hybrid was proposed by Kárpáti (1944) and named as $P . \times$ jávorkae (Kárp.) (P. fruticosa $\times$ P. mahaleb). Hrotkó and Facsar (1996) during field studies identified one specimen of $P$. fruticosa f. aucta living in the habitat Hármashatárhegy (Budapest) as $P . \times$ jávorkae (Kárp.). De Palma et al. (1996) reported about artificial hybridization of $P$. fruticosa $\times P$. mahaleb which resulted in a very low fruit set and germination of seeds. The offspring were triploid $(2 n=3 x=24)$ 
and possessed obtuse leaf bases; the leaf base insertion and leaf shape was intermediate between $P$. fruticosa and $P$. mahaleb. On the other hand, the hybridization of $P$. mahaleb (female) and $P$. fruticosa (male partner) was not successful, no seeds were obtained.

The cultivated sour cherry ( $P$. cerasus) itself is considered a spontaneous hybrid between $P$. avium and $P$. fruticosa. The basic chromosome number for Prunus is $x=8$. Sour cherry (P. cerasus L.) is an allotetraploid species with 32 chromosomes. It is considered to have arisen through natural hybridization between sweet cherry ( $P$. avium L.) $(2 n=2 x=16)$ and ground cherry, P. fruticosa Pall. $(2 n=4 x=32)$ (Olden and Nybom 1968; Brown et al. 1996). Chloroplast DNA analysis revealed that this hybridization event occurred at least twice to produce sour cherry (Brettin et al. 2000). These results suggest that $P$. fruticosa was the female progenitor of $P$. cerasus, a hybrid species produced by the union of unreduced $P$. avium gametes and normal $P$. fruticosa gametes (Badenes and Parfitt 1995; Tavaud et al. 2004). In case of such Prunus species which lack available whole genome sequence, SSRs and SNPs are and will remain the principal genotyping tools (Aranzana et al. 2019). Simple sequence repeats (SSRs, microsatellites) are the marker of choice for the characterization of genetic diversity within and between plant species because of their high polymorphism, codominant inheritance, multiallelic type, reproducibility and extensive genome coverage in all eukaryotic genomes (García-Gómez et al. 2018). Until now, SSR markers are extensively used in genetic diversity studies in several Prunus species (Dirlewanger et al. 2002; Xu et al. 2004; Liang et al. 2018).

Bors (2005) reported a breeding project for dwarf sour cherries, crossing successfully $P$. fruticosa $\times P$. cerasus or creating further backcrosses ( $P$. fruticosa $\times P$. cerasus $) \times P$. cerasus $(\mathrm{BC} 1)$ and $[(P$. fruticosa $\times P$. cerasus $) \times P$. cerasus $] \times P$. cerasus (BC2) with the primary focus of breeding high winter hardiness within the USDA Zone $2\left(-40{ }^{\circ} \mathrm{C}\right)$. Many $\mathrm{BC} 1$ selections were between $1.75-2.25 \mathrm{~m}$ tall with less than 5 suckers. In the frame of a rootstock research project spontaneous hybrids of $P$. fruticosa have been collected in Hungary (Hrotkó and Facsar 1996); their testing as clonal sweet and sour cherry rootstocks is still in its early stages (Hrotkó et al. 2008; Magyar and Hrotkó 2008, 2013). Both literature data studied and our observations on morphological characters of collected hybrids led to several uncertainties in their classification. However, this information is essential for their usage in rootstock breeding. In order to clarify some doubtful identification and confirm the classification of collected and promising specimen of supposed hybrids, we revisited the in situ habitats and the specimen in our ex situ repository. The morphological characteristics were compared to literature data and genetic analysis using simple-sequence repeat (SSR) markers. The aim of our study was to refine the identification of spontaneous hybrids of $P$. fruticosa under in situ conditions in Hungary and provide further information for their possible utilization in rootstock breeding.

\section{Materials and methods}

Morphology, flowering, fruit set and habitats of $P$. fruticosa taxa

Three habitats of ground cherry ( $P$. fruticosa) in Central-Hungary were researched in 1992-1995 with the aim of collection of various forms and supposed hybrids for further rootstock research: (1) Budapest, Hármashatárhegy, (2) Pázmánd: Kálváriadomb, (3) Visegrád: Kis-Villám). The first one was known from the literature (Kárpáti 1944). On each habitat we found the $P$. fruticosa Pall. shrub-colonies more-or less mixed with those shrubs or shrub colonies which showed distinct morphological differences and were described by botanists as suspected hybrids: $P$. fruticosa f. aucta Borb.; P. × mohácsyana Kárp. and $P . \times$ jávorkae Kárp. Among the supposed hybrid derivatives several specimens were cloned and placed into our rootstock repository.

Based on morphological characters, we classified the ground cherry plants and derivatives while consulting with literature data.

Based on personal observation under in situ conditions we described the morphological characteristics of those hybrid groups compared to the basic species (P. fruticosa f. fruticosa Borb.) and compared to the description found in literature (Borbás 1900; Kárpáti 1944; Krüssmann 1978). Observations on the habitat, environment, flowering (Koller et al. 1996) and fruit set of the $P$. fruticosa taxa were made. 
Genetic analysis of $P$. fruticosa specimens and related cultivated taxa

In 2018, the habitats in Budapest Hármashatár-hegy and Pázmánd Kálvária-domb were revisited to collect samples for SSR analysis from in situ specimens of $P$. fruticosa f. fruticosa, P. fruticosa f. aucta. Six genotypes of $P . \times$ mohácsyana were analyzed from our ex situ repository, one of them $(P . \times$ mohácsyana $3 \mathrm{H})$ was compared to a specimen collected from the in situ shrub colony. Two genotypes of $P . \times$ eminens and one supposed $P . \times$ javorkae were involved in the SSR analysis. For comparison we took samples of $P$. mahaleb L. (3 genotypes), P. avium L. (F12/1 and one in situ collected bird cherry), $P$. mahaleb $\times P$. avium (Ma $\times$ Ma 14, Westwood 1978), P. cerasus 'Victor' (Battistini and Berini 2004) and CAB 11/E, collected from the repository accessions.

DNA analysis, PCR conditions

Genomic DNA was extracted from buds using a DNeasy Plant Mini Kit (Qiagen, Hilden, Germany). DNA concentrations and purification parameters were measured using a Nanodrop ND-1000 Spectrophotometer (Bio-Science, Budapest, Hungary). For microsatellite analysis, a set of 9 SSR primer pairs was selected based on previous reports on different Prunus species: CPSCT012 and CPSCT021 (Mnejja et al. 2004), ВРРCT002, ВРРСТ004, ВРТСТ037, BРTCT038, ВРТCT039, ВРTCT040 (Dirlewanger et al. 2002) and ASSR63 (Xu et al. 2004). For $S$ genotype analysis PCRs with PaConsI consensus primers were conducted according Sonneveld et al. (2001). The forward primer was labelled with 6-FAM fluorescent dye for detection in a capillary genetic analyzer. PCR reactions were performed in a Swift MaxPro thermocycler (Esco Healthcare Pte, Singapore) using the program described for the primers. Approximately 20-80 ng of genomic DNA was used for PCR amplification in a $25 \mu$ reaction volume containing $10 \times$ DreamTaqTM Green buffer (Thermo-Scientific, Waltham, MA, USA) with final concentrations of $4.5 \mathrm{mM} \mathrm{MgCl}_{2}, 0.2 \mathrm{mM}$ of dNTPs, $0.2 \mu \mathrm{M}$ of the adequate primers and $0.75 \mathrm{U}$ of DreamTaq $^{\mathrm{TM}}$ DNA polymerase (Thermo-Scientific) (Table 1).
Allele sizing and data analysis

To check the PCR amplifications, $4 \mu \mathrm{l}$ of PCR products was separated by electrophoresis in $1.2 \%$ TAE agarose gels for $2 \mathrm{~h}$ at $100 \mathrm{~V}$, and DNA bands were visualized by ethidium bromide staining. Fragment lengths were estimated by comparison with the 1-kb DNA ladder (Promega, Madison, USA). To determine the exact size of the fragments, the fluorescently labelled products were run on an automated sequencer ABI Prism 3100 Genetic Analyzer (Applied Biosystems, Budapest, Hungary). For allele sizing (genotyping), GENOTYPER 3.7 software and the GS500 LIZ size standard (Applied Biosystems) were used. For the phylogenetic analysis, each detected allele from SSR and $S$-locus genotyping was scored as present (1) or absent (0). The neighbor-joining algorithm was used to construct a dendrogram based on Jaccard's index using the software PAST $2.17 \mathrm{c}$ (Hammer et al. 2001). Numbers on major branches represent bootstrap supports from 2000 replicates. Principal component analysis (PCA) was also performed using PAST software.

\section{Results}

From the investigated habitats (Budapest: Hármashatárhegy, Pázmánd: Kálváriadomb, Visegrád: Kis-Villám), we found a large diversity of shrubs identified as European ground cherry and ground cherry derivatives. On each habitat of ground cherry, we found shrub colonies in various size, which could be identified as previously described taxa and hybrid derivatives. Based on our observations we compiled those morphological characteristics applicable to distinguish among ground cherry forms and supposed hybrid derivatives and list them in Table 2.

Morphological characteristics of investigated ground cherry hybrids

\section{Prunus fruticosa forma fruticosa Borb.}

This is a shrub with $0.3-0.6 \mathrm{~m}$ height, thin full ripe shoots $(0.8$ to $1 \mathrm{~mm})$ and $5-12 \mathrm{~mm}$ long internodes (Fig. 1). The leaves are small, glossy, glabrous, elliptic to obovate, petioles $4-5 \mathrm{~mm}$ long, leaves 15-30 $\mathrm{mm}$ long and 10-17 $\mathrm{mm}$ wide, tough, leaf edge 
Table 1 All loci developed in different species (SSR and self-incompatibility, $S$ ) analyzed in the Prunus accessions with linkage group of their localization, number of alleles obtained and size range of fragments

\begin{tabular}{lllllc}
\hline Locus name & Linkage group & Species & References & Number of alleles & Size range (bp) \\
\hline BPPCT002 & G2 & Peach & Dirlewanger et al. (2002) & 7 & $166-186$ \\
BPPCT004 & G2 & Peach & Dirlewanger et al. (2002) & 10 & $174-198$ \\
BPPCT037 & G5 & Peach & Dirlewanger et al. (2002) & 18 & $123-182$ \\
BPPCT038 & G5 & PEACH & Dirlewanger et al. (2002) & 17 & $102-154$ \\
BPPCT040 & G4 & peach & Dirlewanger et al. (2002) & 13 & $117-143$ \\
CPSCT021 & G2 & Japanese plum & Mnejja et al. (2004) & 14 & $121-161$ \\
CPSCT012 & G6 & Japanese plum & Mnejja et al. (2004) & 6 & $150-171$ \\
ASSR63 & Unknown & Almond & Xu et al. (2004) & 5 & $150-171$ \\
$S-R$ Nase 1st intron & G6 & Cherry & Sonneveld et al. (2001) & 26 & $234-900$ \\
\hline
\end{tabular}

Table 2 Comparison of morphological characters of Prunus fruticosa and its derivatives

\begin{tabular}{|c|c|c|c|c|c|}
\hline & $\begin{array}{l}P . \text { fruticosa } \mathrm{f} . \\
\text { fruticosa }\end{array}$ & $\begin{array}{l}\text { P. fruticosa } \mathrm{f} . \\
\text { aucta }\end{array}$ & P. $\times$ jávorkae & P. $\times$ mohácsyana & P. $\times$ eminens \\
\hline Height (m) & $0.3-0.6$ & $1-2$ & $1-1.5$ & $1-2$ & $2-3$ \\
\hline $\begin{array}{l}\text { Internode } \\
\text { length } \\
(\mathrm{mm})\end{array}$ & $5-12$ & $10-15$ & $10-15$ & $20-25$ & $25-35$ \\
\hline $\begin{array}{l}\text { Shoot } \\
\text { thickness } \\
(\mathrm{mm})\end{array}$ & $0.8-1$ & $1.2-1.7$ & $1.2-1.7$ & $2-2.5$ & $2-3$ \\
\hline $\begin{array}{l}\text { Laminar } \\
\text { length } \\
(\mathrm{mm})\end{array}$ & $15-30$ & $30-40$ & $30-40$ & $40-60$ & $40-70$ \\
\hline $\begin{array}{l}\text { Laminar } \\
\text { width } \\
\text { (mm) }\end{array}$ & $10-17$ & $15-22$ & $18-22$ & $20-25$ & $30-50$ \\
\hline $\begin{array}{l}\text { Lamina } \\
\text { apex }\end{array}$ & Obtuse & $\begin{array}{l}\text { Blunt or slightly } \\
\text { acute }\end{array}$ & $\begin{array}{l}\text { Slightly } \\
\text { acumi-nate }\end{array}$ & Acuminate & Slightly acuminate \\
\hline $\begin{array}{l}\text { Leaf } \\
\text { shoulder }\end{array}$ & $\begin{array}{l}\text { Shrinking to } \\
\text { petiole }\end{array}$ & $\begin{array}{l}\text { Shrinking to } \\
\text { petiole }\end{array}$ & $\begin{array}{l}\text { Slightly } \\
\text { obtusi-form }\end{array}$ & Shrinking to petiole & Shrinking to petiole \\
\hline $\begin{array}{l}\text { Leaf color, } \\
\text { hairs }\end{array}$ & Green, glabrous & Green, glabrous & $\begin{array}{l}\text { Light green, } \\
\text { glabrous }\end{array}$ & $\begin{array}{l}\text { Dark green, glossy, glabrous, } \\
\text { fein hairy in vein angles }\end{array}$ & $\begin{array}{l}\text { Dark green, vain angles } \\
\text { hairy }\end{array}$ \\
\hline Fruit & $\begin{array}{l}\text { 12-14 mm } \\
\text { flattened globose, } \\
\text { short pedicle }\end{array}$ & $\begin{array}{l}12-15 \mathrm{~mm} \\
\text { flattened } \\
\text { globose, long } \\
\text { pedicle }\end{array}$ & No fruits & $\begin{array}{l}\text { 14-17 mm elongated globose, } \\
\text { pedicle long }\end{array}$ & $\begin{array}{l}\text { 13-17 mm flattened } \\
\text { globose, long pedicle } \\
40-50 \mathrm{~mm}\end{array}$ \\
\hline $\begin{array}{l}\text { Stone } \\
\text { (endo- } \\
\text { carpium) }\end{array}$ & $\begin{array}{l}6-8 \times 4-6 \mathrm{~mm} \\
\text { ovoid, ribs } \\
\text { around scab }\end{array}$ & $\begin{array}{l}7-9 \times 4-6 \mathrm{~mm} \\
\text { ovoid, ribs } \\
\text { around scab }\end{array}$ & No fruits & $\begin{array}{l}7-9 \times 4-6 \mathrm{~mm} \text {, basal end } \\
\text { culminating, ribs along } \\
\text { abdominal seams }\end{array}$ & $\begin{array}{l}7-9 \times 4-6 \mathrm{~mm} \text {, ovoid, } \\
\text { ribs around scab }\end{array}$ \\
\hline
\end{tabular}

jaggy, leaf tip obtuse, lamina shrinking to the petiole. Its flowers grouped 2-4, small in sessile umbels, white, about $1.5 \mathrm{~cm}$ wide in late April. Flowers open 10 to 20 days after $P$. avium, while flowers of $P$. mahaleb open 1 week or few days before $P$. fruticosa. The fruits are globule, slightly flattened, 12-14 mm wide, dark red, sour, $20-30 \mathrm{~mm}$ pedicels. Its stone are ovoid, 7-9 $\mathrm{mm}$ long and 4-6 $\mathrm{mm}$ wide, the tip is blunt 


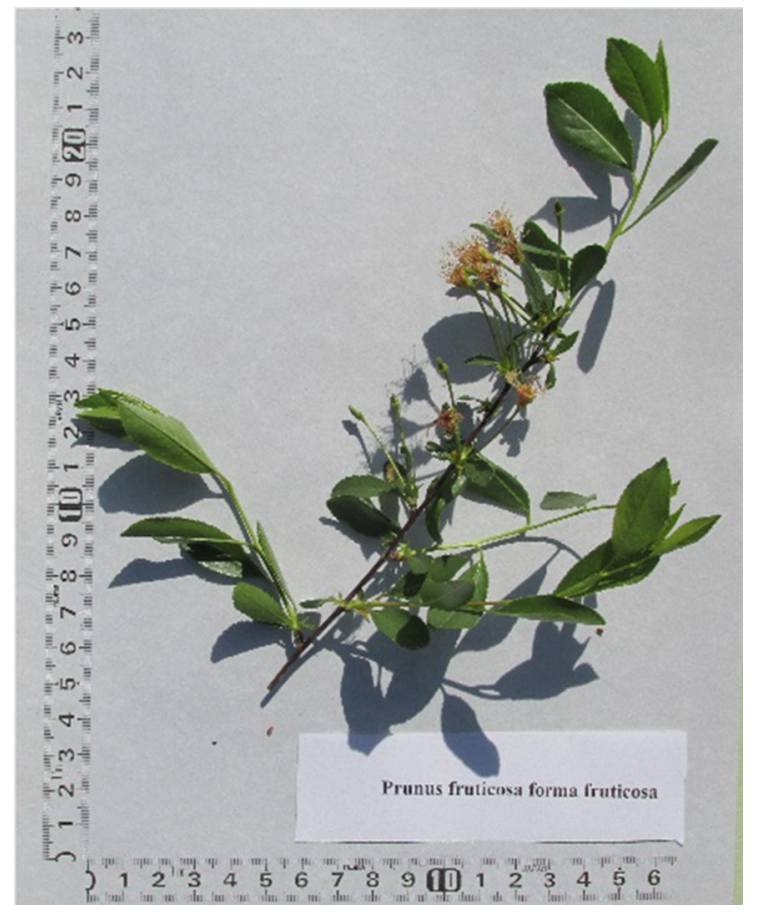

Fig. 1 Prunus fruticosa forma fruticosa shoot in situ collected

or acute, the basal end around the scab is slightly ribbed. As the shrub forms stolons (runners) which produces suckers, the shrub colony supposedly consist of a mixture of clonally identical plants and seedlings. In habitats of Hármashatárhegy and Nagy-Villám, some shrub colonies are mixed with higher shrubs, identified as $P$. fruticosa f. aucta.

\section{Prunus fruticosa forma aucta Borb.}

Upright growing shrub to 1-2 m height, even shorter types develop a definite small trunk (Fig. 2). The shoots are a little thicker than that of $P$. fruticosa $\mathrm{f}$. fruticosa, 1.2-1.7 mm thick and it has 10-15 $\mathrm{mm}$ long internodes. Its leaves are little larger than P. fruticosa f. fruticosa, glossy, glabrous, wide lanceolate, little wavy (undulated), petioles $10-15 \mathrm{~mm}$ long. The leaves are $30-40 \mathrm{~mm}$ long and $15-22 \mathrm{~mm}$ wide, tough, leaf edge jaggy, leaf tip acuminate, shrinking to the petiole. The flowers are grouped 2-4, small, in sessile umbels, white, about $1.5 \mathrm{~cm}$ wide in April, mostly sterile, rarely set fruits. The fruits are flattened globose, 12-15 mm, dark red, sour, with pedicles of $30-40 \mathrm{~mm}$. The stones are wide ovoid, 7-9 mm long and 4-6 mm wide, with blunt acute tips, slightly

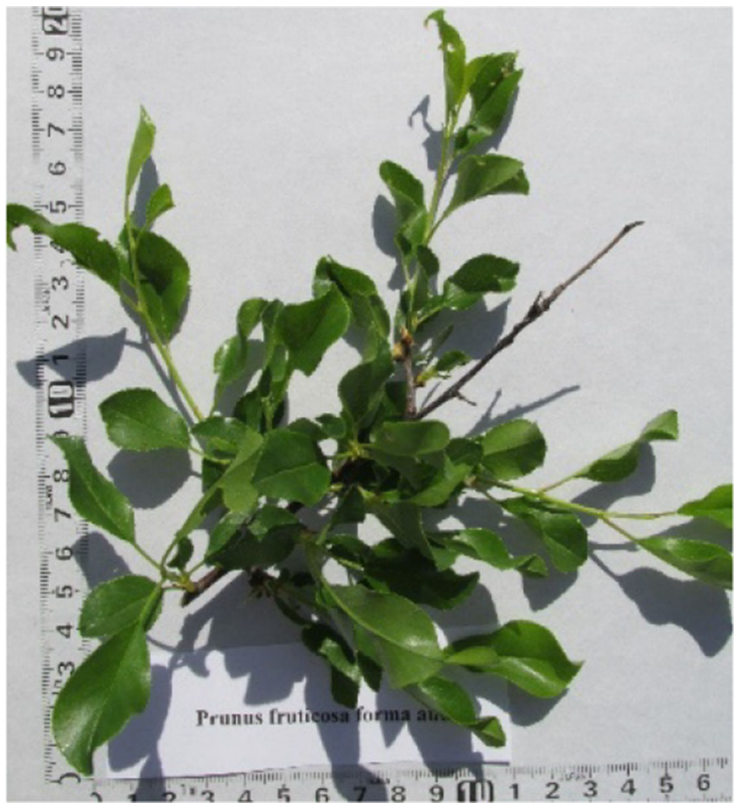

Fig. 2 Leaves and shoots of Prunus fruticosa forma aucta in situ collected

ribbed around the scab on basal end. Specimen of this taxa occur usually mixed with $P$. fruticosa f. fruticosa.

Prunus $\times$ jávorkae Kárp. $(P$. fruticosa $\times P$. mahaleb): A few specimens of $P$. fruticosa f. aucta, especially those found in shady areas, showed similar leaf shape to that specimen which was identified by Kárpáti (1944) as $P . \times$ jávorkae Kárp. (P. fruti$\cos a \times P$. mahaleb). The shoots are fine hairy, leaves glossy, glabrous, obovate, little wavy (undulated), petioles $10-15 \mathrm{~mm}$ long, leaves $30-40 \mathrm{~mm}$ long and 18-22 mm wide, tough, leaf edge jaggy, leaf tip acuminate, shrinking to the petiole or slightly obtuse leaf bases. The leaf base insertion and leaf shape is intermediate between $P$. fruticosa and $P$. mahaleb (Fig. 3).

Prunus $\times$ mohácsyana Kárp.: This upright growing shrub reaches $1-2 \mathrm{~m}$ in height. The shoots are 2-2.5 mm thick 20-25 mm long internodes, glabrous (Fig. 4). Leaves are larger than P. fruticosa forma fruticosa, glossy, glabrous, wide lanceolate, petioles 10-15 mm long, leaves 40-60 mm long and 20-25 mm wide, tough, leaf edge sawn, leaf tip acuminate, shrinking to the petiole. Flowers grouped 2-4, small in sessile umbels, white, about $1.5 \mathrm{~cm}$ wide in late April, mostly sterile, rare sets fruits. The fruits are elongated globose, $14-17 \mathrm{~mm}$, dark red, sour, $30-40 \mathrm{~mm}$ pedicel. Stones are elongated ovoid, 


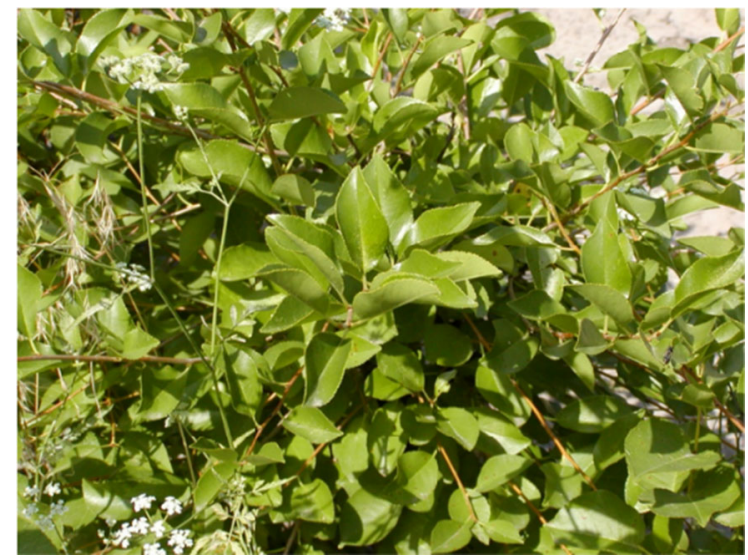

Fig. 3 Shoots and leaves of Prunus $\times$ jávorkae (ex situ collection)

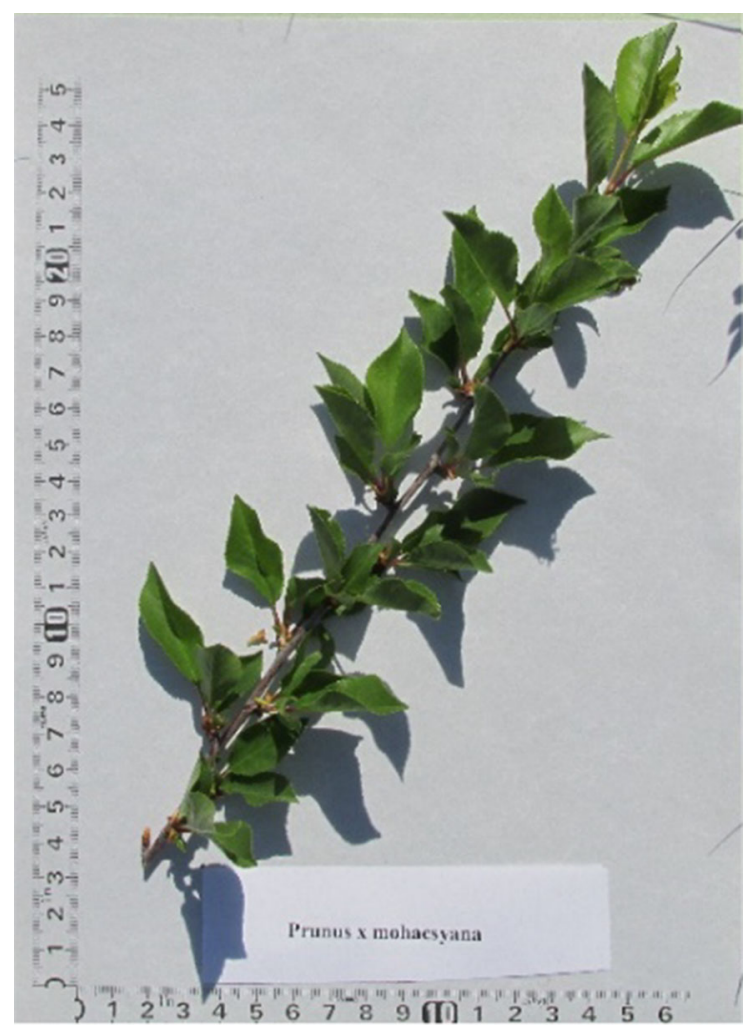

Fig. 4 Shoots and leaves of Prunus $\times$ mohácsyana $3 \mathrm{H}$ in situ collected

7-9 $\mathrm{mm}$ long and 4-6 mm wide, tip is blunt acute, on basal end culminating, around scab few ribs, along the flat abdominal seams $2-3$ ribs.

Prunus $\times$ eminens Beck: This shrub or small tree has a loose, spreading canopy, reaching 1-2 m height.
The shoots are $2-3 \mathrm{~mm}$ thick, leaves are large, $40-70 \mathrm{~mm}$ long and $30-50 \mathrm{~mm}$ wide, abaxial side is fine hairy in vein angles, petioles are 10-15 mm long. The fruits are globose, 13-17 mm, dark red, sour, pedicle $40-50 \mathrm{~mm}$. The stone is little elongated ovoid, small, around the basal scab ribbed, similar to sour cherry (Fig. 5).

Results of SSR analysis

\section{Genetic distances}

A total of 9 SSR loci were screened using primers designed for different Prunus species (Dirlewanger et al. 2002; Mnejja et al. 2004;. Xu et al. 2004). All these widely used loci were chosen based on previously detected polymorphism level. Amplification was not successful in some genotypes with BPTCT039 primers, and hence, those data were excluded from the evaluation process. The remaining 8 loci proved to be polymorphic. In each genotype, 1-4 alleles were

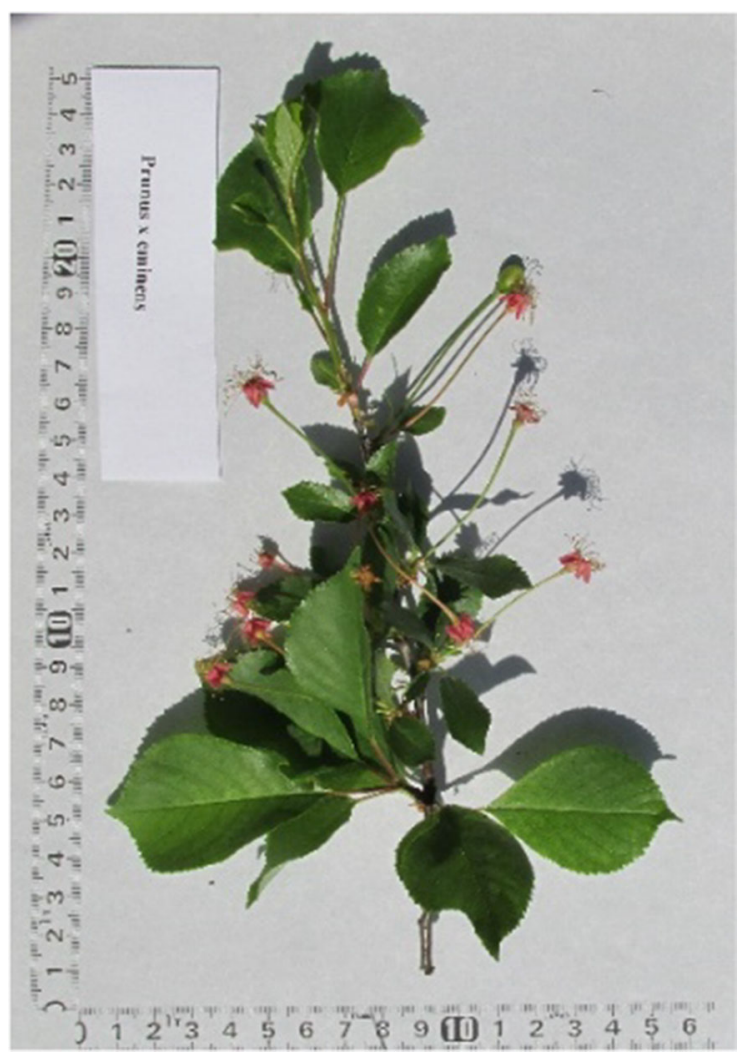

Fig. 5 Prunus $\times$ eminens $3 \mathrm{H}$ (shoot, leaves and fruit), collected in situ 
scored due to different ploidy level of the accessions. As expected, tetraploid, triploid and diploid genotypes amplified 4, 3 and 2 alleles in each locus, respectively. In cases where the number of detected alleles was lower than the expected number, we hypothesized that one or two of the alleles were present in more copies.

Altogether, the primer pairs produced a total of 90 alleles ranging from 5 to 18 alleles per locus (average allele number 11.2). A wide range of fragment length was detected among the accessions from 102 to $198 \mathrm{bp}$ (Table 3). The 8 SSR markers displayed relatively high polymorphism levels: BPTCT037 had the largest number of alleles (18), while ASSR63 amplified the smallest number of alleles (5). Each of the 24 genotypes could be characterized by unique SSR fingerprints since all loci showed high allele number.
Based on SSR data, the level of ploidy can be predicted but homozygosity may not allow the precise determination of the copy number of given alleles. $P$. avium, $P$. mahaleb and $P$. mahaleb $\times$ avium genotypes showed two alleles in all loci, while $P$. cerasus and $P$. fruticosa accessions presented 4 alleles in 5 loci. $P . \times$ eminens genotypes were characterized by 4 alleles in 3 loci, while $P . \times$ mohácsyana hybrids showed 3 alleles in 7 loci. $P . \times$ jávorkae plant seemed to be triploid having 3 alleles in 3 loci (Table 3 ).

Most Prunus species are self-incompatible governed by the highly polyallelic $S$-locus (Hegedüs et al. 2012). The SSR profiling of 24 Prunus genotypes was completed with the characterization of the first intron region in S-RNase gene. Using the intron length polymorphism (ILP) marker strategy, this locus proved to be the most polymorphic since altogether 26 alleles with precise size (234-900 bp) were scored.

Table 3 Supposed ploidy level of taxa involved in molecular analysis

\begin{tabular}{|c|c|c|}
\hline Name & Origin & Supposed ploidy level \\
\hline \multicolumn{3}{|l|}{ Taxa from spontaneous origin } \\
\hline Prunus avium & In situ collected, Budapest, Hármashatárhegy & Diploid \\
\hline Prunus fruticosa f. fruticosa, & In situ collected, Budapest, Hármashatár hegy & Tetraploid \\
\hline Prunus fruticosa f. aucta, & In situ collected, Pázmánd, Kálvária domb & Tetraploid \\
\hline Prunus fruticosa hybrid 'Prob' & Tall genotype from seed collection of Kárpáti (1944) & Tetraploid \\
\hline Prunus fruticosa 'Globosa' & Buda Arboretum, top grafted ornamental & Tetraploid \\
\hline Prunus $\times$ mohácsyana $\mathrm{PZ2}$ & Ex situ repository, origin Pázmánd, Kálvária domb, & Triploid \\
\hline Prunus $\times$ mohácsyana $\mathrm{PZ3}$ & Ex situ repository, origin Pázmánd, Kálvária domb & Triploid \\
\hline Prunus $\times$ mohácsyana $\mathrm{PZ5}$ & Ex situ repository, origin Pázmánd, Kálvária domb & Triploid \\
\hline Prunus $\times$ mohácsyana $\mathrm{KV} 2$ & Ex situ repository, origin Visegrád, Kis Villám & Triploid \\
\hline Prunus $\times$ mohácsyana Arboretum & Buda Arboretum, top grafted ornamental & Triploid \\
\hline Prunus $\times$ mohácsyana $3 \mathrm{H}$ in situ & In situ collected, Budapest, Hármashatárhegy & Triploid \\
\hline Prunus $\times$ mohácsyana $3 \mathrm{H}$ ex situ & Ex situ repository, origin Budapest, Hármashatárhegy & Triploid \\
\hline Prunus $\times$ eminens $3 \mathrm{H}$ & In situ collected, Budapest, Hármashatárhegy & Tetraploid \\
\hline Prunus $\times$ eminens $\mathrm{KV} 2$ & Ex situ repository, origin Visegrád, Kis Villám & Tetraploid \\
\hline Prunus $\times$ javorkae & Ex situ repository, origin Budapest, Hármashatárhegy & Triploid \\
\hline \multicolumn{3}{|l|}{ Taxa from cultivated origin } \\
\hline Prunus cerasus 'Victor' & Ex situ repository, propagated as rootstock in Italy & Tetraploid \\
\hline Prunus cerasus $\mathrm{CAB} 11 \mathrm{E}$ & Ex situ repository, propagated as rootstock in Italy & Tetraploid \\
\hline Prunus avium F12/1 & Ex situ repository, propagated as rootstock & Diploid \\
\hline Prunus $\mathrm{Ma} \times \mathrm{Ma} 14(P$. mahaleb $\times P$. avium $)$ & Ex situ repository, propagated as rootstock & Diploid \\
\hline Prunus mahaleb 'Bogdány' & Ex situ repository, propagated as rootstock & Diploid \\
\hline Prunus mahaleb 'Magyar' & Ex situ repository, propagated as rootstock & Diploid \\
\hline Prunus mahaleb 'Dalmata' & Ex situ repository, selected for rootstock breeding & Diploid \\
\hline
\end{tabular}


As it was expected, several common $S$-alleles were identified in different species which is the consequence of natural hybridization events. The number of different $S$-alleles in case of the tested genotypes proved very similar to the case of SSR loci: 4 alleles were $P$. cerasus and $P$. fruticosa, 3 alleles in $P . \times$ mohácsyana hybrids and $P . \times$ jávorkae, while 2 alleles were caught in $P$. avium, $P$. mahaleb and $P$. mahaleb $\times$ avium genotypes.

\section{Estimation of genetic distance}

The genetic relationships among the tested Prunus hybrids were depicted using neighbor-joining cluster analysis (Fig. 6). Cluster analysis revealed genetic relationships among accessions, samples were clustered into five main groups of different size according to their genetic distance. The first main group contains $P$. emines and $P$. cerasus, the second main group includes $P . \times$ mohácsyana series, the third groups consists of $P$. fruticosa and its cultivars, and the fourth group contains $P$. mahaleb and $P . \times$ javorkae genotypes, while $P$. avium genotypes separate from the others (Fig. 6).

Principal component analysis (PCA) (Fig. 7) confirmed the details revealed by the dendrogram and gave further information. The first two principal axes accounted for 18.7 and $8.9 \%$ of the total variation, respectively. PCA scatter plots clearly proved that $P$. mahaleb genotypes formed a separate group with great genetic distance from the rest of the tested accessions. $P . \times$ mohácsyana accessions diverged to two small groups, while $P$. fruticosa genotypes were placed between $P$. avium and $P$. cerasus.

\section{Discussion}

From all the three investigated habitats of European ground cherry, we identified the $P$. fruticosa and its supposed hybrid derivatives using morphological characteristics. Although the ground cherry is
Fig. 6 Neighbor-joining dendrogram of Jaccard indices among 22 Prunus hybrids based on SSR and $S$ locus analysis. Numbers indicate bootstrap values (percentage of 1000 replicates). Bootstrap values greater than $50 \%$ are shown

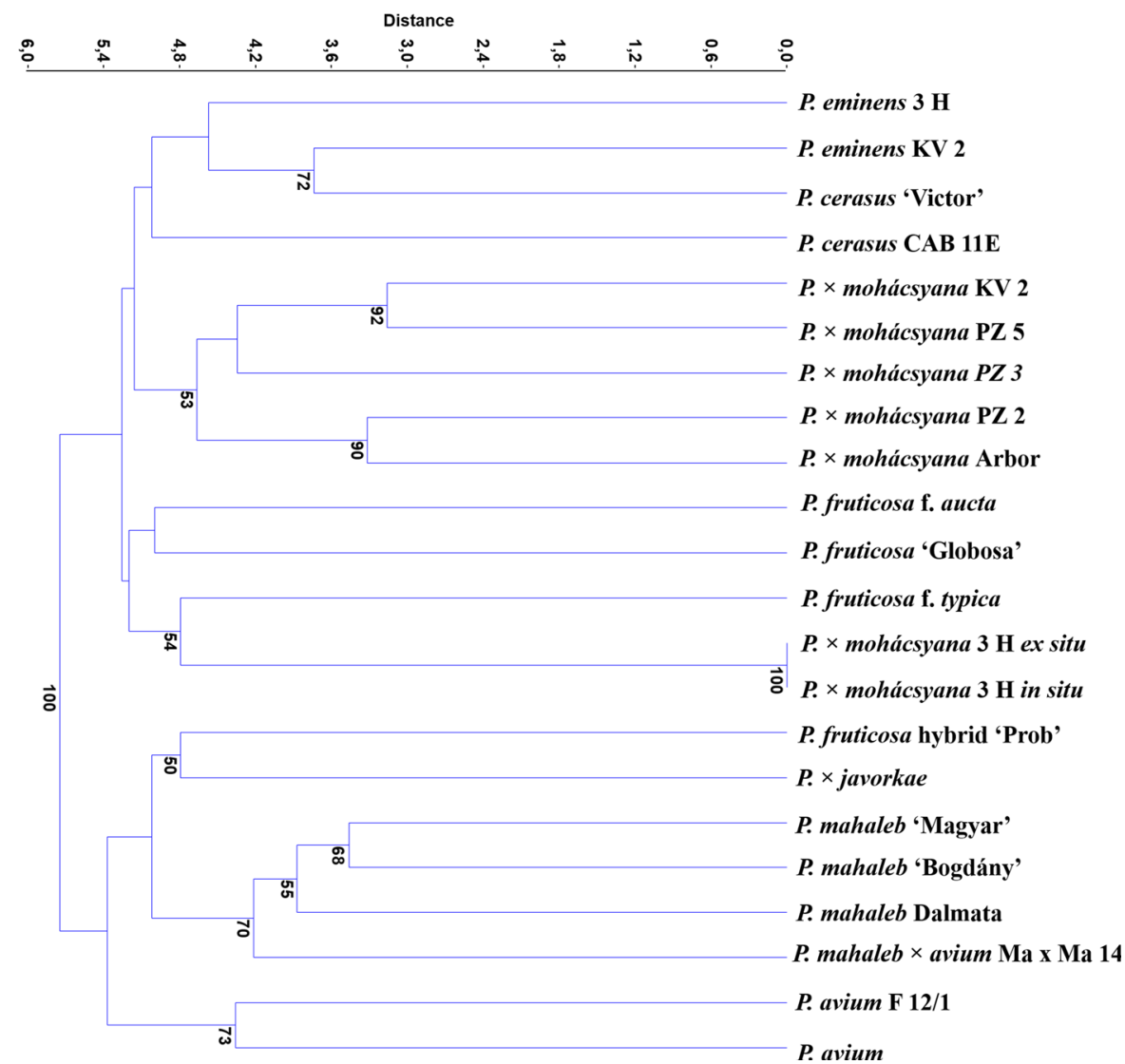




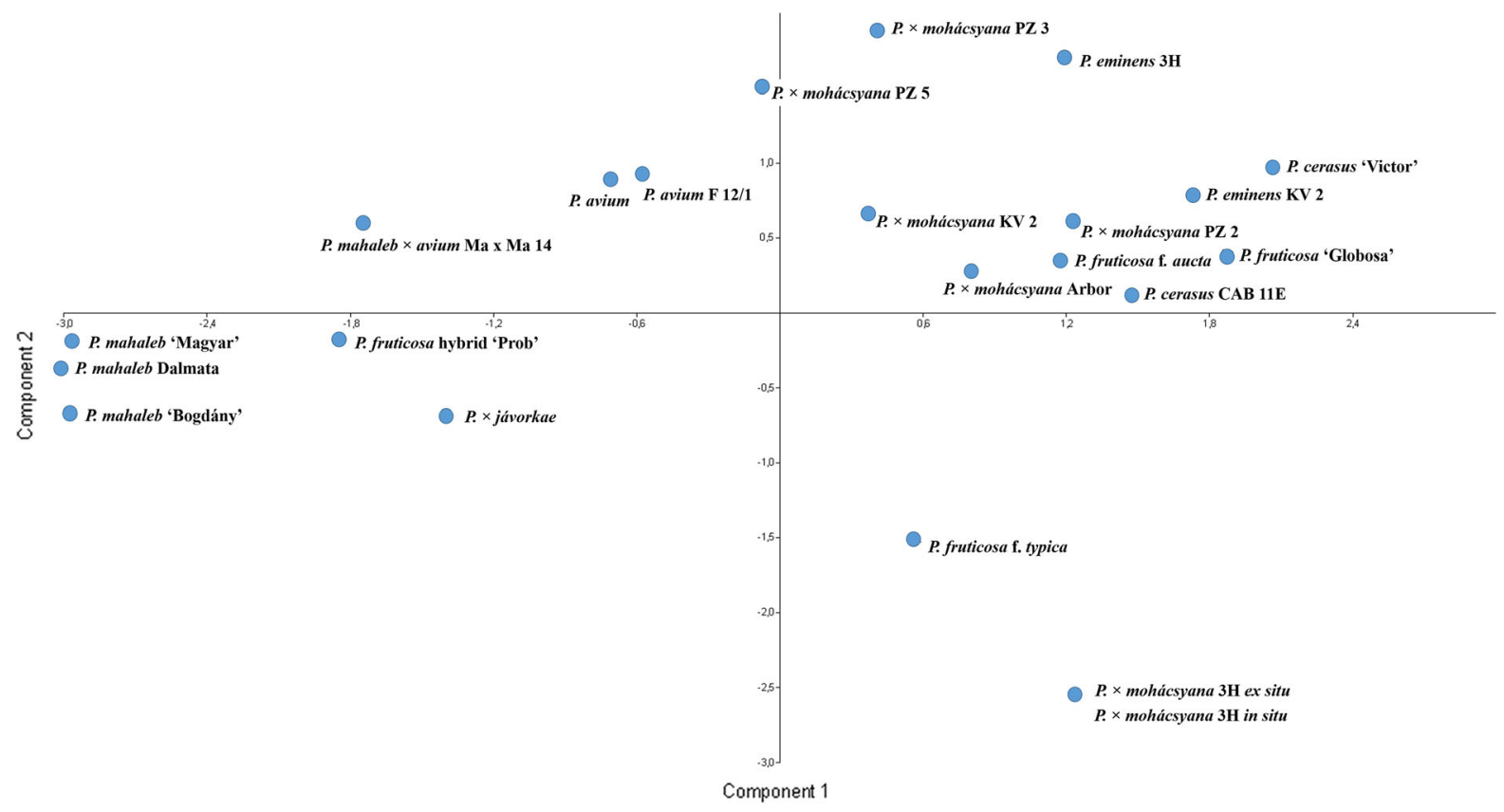

Fig. 7 Distribution of Prunus taxa on the two first PCA axes determined from SSR and S-locus genotyping

considered as relict of steppe vegetation from ancient time, the shrub colonies in Budapest-Hármashatárhegy after almost 80 years are still found in the same habitat (Kárpáti 1944), which is a good sign of the vitality and survival capacity of these taxa. Our study on morphological characterization confirmed their botanical description as taxa with diverse variability (Krüssmann 1978; Rehder 1990). This variability is high enough to emphasize that the hybrid derivatives largely differ from the basic form of ground cherry. What is more, for further breeding projects using $P$. fruticosa, the information on genetic constitution is essential.

The genetic analysis support our opinion and it is in correspondence with results of Barać et al. (2013, 2017) and Macková et al. (2017). Based on genetic analysis we confirmed our earlier observation that in most of habitats the European ground cherry is an admixture or in certain habitats overgrown by hybrid derivatives. The hybrid derivatives of the species as seedlings occur within the shrub colonies in the same habitat, which causes the seemingly large variability.

Our genetic analysis positioned both diploid species Prunus avium and $P$. mahaleb into distinct groups while the MaxMa 14 (P. mahaleb $\times$ P. avium,
Westwood 1978) proved to be diploid too and was placed in between the two parent species (Fig. 7).

Considering the morphological characters the $P$. fruticosa f. fruticosa and P. fruticosa f. aucta are hardly distinguishable, the only difference is the height of the plants and the little larger leafs (Table 2; Figs. 1,2). The genetic analysis did not provide any contribution to distinguish the two forms, however, both the $P$. fruticosa f. aucta and P. fruticosa 'Globosa' were distributed on the two first PCA axes determined from SSR and $S$-locus genotyping among group of hybrids in contrary to $P$. fruticosa $\mathrm{f}$. fruticosa. The neighbor joining dendrogram clustered all the three taxa close to each other (Fig. 6). The genetic analysis of the sample of ground cherry collected in situ on Hármashatár-hegy (Buda Hills) suggests that the specimen of $P$. fruticosa f. fruticosa $3 \mathrm{H}$ is tetraploid $(2 n=4 x=32)$ which is in correspondence with Olden and Nybom (1968) and Brown et al. (1996). The neighbor-joining dendrogram of Jaccard indices shows some relationship with P. fruticosa $\mathrm{f}$. aucta and $P$. fruticosa 'Globosa', however the bootstrap values are less than $50 \%$. Morphological characters of $P$. fruticosa 'Globosa' are similar to $P$. fruticosa f. aucta, its globose form allows the usage as top-worked ornamental tree (Krüssmann 1978). As the 
distribution by PCA axes clustered both P. fruticosa $\mathrm{f}$. aucta and P. fruticosa 'Globosa' into the group of hybrids, the conclusion is that further investigation is needed among the f. aucta group with large population of accessions for clearer identification.

The $P$. fruticosa hybrid 'Prob' by our observation shows similar morphological characters to P. fruticosa f. aucta. This clone was selected by Probocskai (1982, personal communication) as a tall seedling from among ground cherry offspring, collected by Kárpáti (1944) and tested as dwarf cherry rootstock by Magyar and Hrotkó (2008, 2013), although 'Prob' seems to be tetraploid, the dendrogram (Fig. 6) shows some relationship with $P . \times$ jávorkae (bootstrap value is $50 \%$ ). This hybrid was placed close to the group of $P$. mahaleb and $P . \times$ jávorkae based on the two first PCA axes determined from SSR and $S$-locus genotyping. Our conclusion is that the identification of the possible origin of this hybrid is still not clear. P. $\times$ jávorkae might be based on the same ground cherry population from the site of Buda Hills. The fact that among the $P$. fruticosa (short type) shrub-colony randomly occur tall f. aucta genotype, suggest that among those tall f. aucta plants, there might be several hybrid derivatives. Besides morphological characters, our genetic analysis support that both $P . \times$ mohácsyana and $P . \times$ javorkae are triploid hybrids of $P$. fruticosa in consonance with the supposition of Kárpáti (1944).

Spontaneous crosses between related species may occur when the natural habitat and the flowering time overlap (Faust and Surányi 1997). As the flowers of $P$. fruticosa are self-incompatible (Koller et al. 1996), within the shrub colony, which spreads by runners or suckers, the potential of cross-pollination is low and so the spreading by seed is limited. On the contrary, diverse seedling populations of ground cherry in our ex situ repository under cultivated conditions produced abundant fruits. The chance for pollination of flowers by other possible compatible species (P. avium and $P$. mahaleb) is rather low, because of the late flowering of ground cherry. Pollination of ground cherry by $P$. avium as male parent is possible in such years, where the flowering runs fast, pollen of late flowers of bird cherry may fertilize the early flowers of ground cherry where the proterogyn pistils (Koller et al. 1996) may receive $P$. avium pollen. The chance for the opposite pollination $(P$. avium $\times P$. fruticosa) as reported by Kárpáti (1944), are attributable to the earlier opened and fertilized flowers, dry pistils of bird cherry is rather low, possible in years only, when the overlapping of flowering time is given. Much larger is the opportunity of pollination by $P$. mahaleb, because its flowers open close to the flowering time of ground cherry.

We (Hrotkó and Facsar 1996) explored from among $P$. fruticosa f. aucta plants accessions of $P . \times$ jávorkae Kárp. (P. fruticosa $\times$ P. mahaleb) in Budapest, Hármashatár-hegy (Table 2, Fig. 3). In agreement with De Palma et al. (1996) who created artificial hybrids between $P$. fruticos $a$ and $P$. mahaleb, the leaf base insertion and leaf shape was intermediate between parents. This hybrid derivative was named by Kárpáti (1944) based on one single herbarium specimen only, on which the explorer Jávorka made a notice that this might be a hybrid between $P$. fruticosa $\times P$. mahaleb. Morphologically, we identified few specimens of $P . \times$ jávorkae, we can state that this hybrid derivative may occur in other habitats. Our genetic analysis suggests that the sample of shrubs that we identified as $P . \times$ jávorkae is triploid and show genetic similarity to $P$. mahaleb (Figs. 6, 7). This triploid hybrid is due to the flower sterility representing a blind alley in the evolution and limited usage in rootstock breeding.

We found on each investigated habitat specimens of the supposed hybrid derivatives of European ground cherry, which were named by Kárpáti (1944) $P . \times$ mohácsyana. The hybrid derivative $P . \times$ mohácsyana showed clearly distinct morphological characters as it was described by Kárpáti (1944) and Macková et al. (2017). The phenotypic characters of this group are easily distinguishable from the P. fruticosa f. fruticosa and f. aucta (Table 2, Fig. 4). Due to taller growth and thicker shoots this hybrid attracted the attention of most rootstock researchers (Hrotkó et al. 2008; Ljubojević 2018 personal communication): for nursery liners their cuttings seem preferable. This derivative of ground cherry occurs on several habitats of Carpathian basin outside Hungary in Slovakia (Macková et al. 2017) and in Serbia (Ljubojević 2018 personal communication). Our study is consistent with Macková et al. (2017) who suggests that $P . \times$ mohácsyana Kárp. is a triploid hybrid but due to the sterility represents a blind alley in evolution. Kárpáti (1944) supposed that it was a hybrid of $P$. avium (female parent) pollinated by $P$. fruticosa, however, considering our observation on flowering time the opposite is 
more likely: of $P$. fruticosa $\times$ of $P$. avium. The dendrogram (Fig. 6) suggests close relationship between $P$. fruticosa f. fruticosa and $P . \times$ mohácsyana $3 \mathrm{H}$ specimen (collected from the same habitat), which supports our claim that in this habitat the $P . \times$ mohácsyana $3 \mathrm{H}$ is a hybrid of $P$. fruticosa $\mathrm{f}$. fruticosa. Furthermore, $P . \times$ mohácsyana $3 \mathrm{H}$ ex situ (specimen collected in 1993 from the shrub colony) and in situ specimen (collected in 2018 from different side of the same shrub colony) showed $100 \%$ identity, which proves that the two specimen is derived from the same clone. The spreading trait by runners is a limitation of this hybrid, as the flowers are mostly sterile, rarely sets fruits, and the seeds do not germinate by our observation. This confirms the report by Macková et al. (2017) that the chance for backcross formation or for occupying the habitat of basic form ground cherry by $P . \times$ mohácsyana is rather low. This limits the usage of this hybrid derivative for further cross-breeding, but the evaluation of spontaneous hybrids may result in selection of promising rootstock genotype (Hrotkó et al. 2008).

In some investigated habitats, we found few specimens identified by morphological characters (Table 2, Fig. 5) as $P . \times$ eminens. Our genetic analysis suggests that all the samples are tetraploid, fertile hybrid derivative of ground cherry occurring in some habitats of the basic species and show similar morphological characters to the cultivated sour cherry. The bootstrap value between $P . \times$ eminens $\mathrm{KV} 2$ and P. cerasus 'Victor' is $72 \%$ (Fig. 6), which indicate close relationship. The position of both taxa on the two PCA axes (Fig. 7) supports the genetic similarity. In agreement with Kárpáti (1944) we suggest considering this hybrid derivative $(P . \times$ eminens $)$ as hybrid of $P$. avium $\times P$. fruticosa. Such crosses (Olden and Nybom 1968) might have been created spontaneously and further human selection resulting in the cultivated forms of sour cherry (Fig. 5).

\section{Conclusion}

The hybrid derivatives of $P$. fruticosa as seedlings occur within the shrub colonies in the same habitat, which causes the seemingly large variability. Our results support the triploid character of that hybrid group, which was explored and identified as $P . \times$ mohácsyana Kárp. Genetic analysis of specimen of
$P . \times$ jávorkae Kárp. (P. fruticosa $\times P$. mahaleb $)$ indicated that it is triploid and show genetic relation to $P$. mahaleb. Genetic analysis suggests that specimens identified as $P . \times$ eminens Beck. are tetraploid, fertile hybrid derivative of ground cherry occurring in some habitats. Most probably it is hybrid between $P$. avium $\times$ P. fruticosa.

Acknowledgements Open access funding provided by Szent István University (SZIE). Authors acknowledge the valuable support of TÉT_16_CN-1-2016-0014 research project financed by the National Research, Development and Innovation Office. This research was supported by the Higher Education Institutional Excellence Program (20430-3/2018/ FEKUTSTRAT) awarded by the Ministry of Human Capacities within the framework of plant breeding and plant protection researches of Szent István University. The authors thank Márta Gyeviki for his helpful comments and are grateful to Nathan Lemon for critically revising the English of the manuscript.

\section{Compliance with ethical standards}

Conflict of interest The authors declare that they have no conflict of interest.

Human and animal rights This article does not contain any studies with human or animal subjects.

Open Access This article is distributed under the terms of the Creative Commons Attribution 4.0 International License (http:// creativecommons.org/licenses/by/4.0/), which permits unrestricted use, distribution, and reproduction in any medium, provided you give appropriate credit to the original author(s) and the source, provide a link to the Creative Commons license, and indicate if changes were made.

\section{References}

Aranzana MJ, Decroocq V, Dirlewanger E, Eduardo I, Gao ZS, Gasic K, Iezzoni A, Jung S, Peace C, Prieto H, Tao R, Verde I, Abbott AG, Arús P (2019) Prunus genetics and applications after de novo genome sequencing: achievements and prospects. Hortic Res 6:58. https://doi.org/10. 1038/s41438-019-0140-8

Badenes ML, Parfitt DE (1995) Phylogenetic relationships of cultivated Prunus species from an analysis of chloroplast DNA variation. Theor Appl Genet 90(7-8):1035-1041. https://doi.org/10.1007/BF00222918

Barać G, Ognjanov V, Obreht D, Ljubojević M, Bošnajković Pejić I, Gašić K (2013) Genotypic and phenotypic diversity of cherry species collected in Serbia. Plant Mol Biol Rep. https://doi.org/10.1007/s11105-013-0601-4

Barać G, Ognjanov V, Vidaković DO, Dorić D, Ljubojević M, Dulić J, Miodragivić M, Gašić K (2017) Genetic diversity and population structure of European ground cherry (Prunus fruticosa Pall.) using SSR markers. Sci Hortic 
224:374-383. https://doi.org/10.1016/j.scienta.2017.06. 060

Battistini A, Berini ES (2004) Agronomic results of Victor, a semi-dwarf cherry rootstock. Acta Hortic 658:111-113

Beck J (1893) Flora von Nieder- Österreich 2: 821

Borbás V (1900) A Balaton flórája 2. rész. (Flora of Lake Balaton, part 2) A Magyar Földrajzi Társaság BalatonBizottságának kiadványa. Budapest, p 420

Bors RH (2005) Dwarf sour cherry breeding at the University of Saskatchewan. Acta Hortic 667:135-140

Brettin TS, Karle R, Crowe EL, Iezzoni AF (2000) Brief communication. chloroplast inheritance and DNA variation in sweet, sour, and ground cherry. J Hered 91(1):75-79. https://doi.org/10.1093/jhered/91.1.75

Brown SK, Iezzoni AF, Fogie HW (1996) Cherries. In: Janick J, Moore JN (eds) Fruit breeding. Tree and tropical fruits, vol 1. Wiley, New York, pp 213-255

Cummins NJ (1972) Vegetatively propagated selections of Prunus fruticosa as dwarfing stocks for cherry. Fruit Var Hort Dig 26:76-79

De Palma L, Palasciano M, Godini A (1996) Interspecific hybridization program aimed at obtaining dwarfing and non-suckering rootstocks for sweet cherry. Acta Hortic 410:177-181. https://doi.org/10.17660/ActaHortic.1996. 410.26

Dirlewanger E, Cosson P, Tavaud M, Aranzana M, Poizat C, Zanetto A, Arús P, Laigret F (2002) Development of microsatellite markers in peach $[$ Prunus persica (L.) Batsch] and their use in genetic diversity analysis in peach and sweet cherry (Prunus avium L.). Theor Appl Genet 105:127-138. https://doi.org/10.1007/s00122-002-0867-7

Dzhangaliev AD, Salova TN, Turekhanova PM (2003) The wild fruit and nut plants of Kazakhstan. In: Janick J (ed) Horticultural reviews. Wiley, Hoboken, pp 305-371

Eremin V, Eremin G (2002) The perspective of clonal rootstocks for Prunus at Krymsk Breeding Station, Russia. In: First international symposium for deciduous fruit tree species, Zaragoza, 11-14 June, Abstract: S5-5

Eremin GV, Provorčenko AV, Gavriš VF, Podorožnij VN, Eremin VG (2000) Kostočkovie kuljturi: Virašćivanie na klonovih podvojah i sobstvenih kornjah. Feniks, Rostov na Donu

Faust M, Surányi D (1997) Origin and dissemination of cherry. Hortic Rev 19:263-317

García-Gómez B, Razi M, Salazar JA, Prudencio AS, Ruiz D, Dondini L, Martínez-Gómez P (2018) Comparative analysis of SSR markers developed in exon, intron, and intergenic regions and distributed in regions controlling fruit quality traits in prunus species: genetic diversity and association studies. Plant Mol Biol Rep 36:23. https://doi. org/10.1007/s11105-017-1058-7

Gruppe W (1985) An overview of the cherry rootstock breeding program at Giessen. Acta Hortic 169:189-198. https://doi. org/10.17660/ActaHortic.1985.169.27

Hammer R, Harper DAT, Ryan PD (2001) PAST: paleontological statistics software package for education and data analysis. Palaeontol Electron 4:1-9

Hegedűs A, Lénárt J, Halász J (2012) Sexual incompatibility in Rosaceae fruit tree species: molecular interactions and evolutionary dynamics. Biol Plant 56(2):201-209. https:// doi.org/10.1007/s10535-012-0077-3
Hein K (1979) Zwischenbericht über eine Prüfung der Steppenkirsche ( $P$. fruticosa) und anderen Süsskirchenunterlagen und Unterlagenkombinationen. Erwerbsobstbau 21:219

Hrotkó K (2004) Cherry rootstock breeding at the department of fruit science, Budapest. Acta Hortic 658:491-495. https:// doi.org/10.17660/ActaHortic.2004.658.73

Hrotkó K, Facsar G (1996) Taxonomic classification of Hungarian populations of Prunus fruticosa (Pall.) Woronow hybrids. Acta Hortic 410:495-498

Hrotkó K, Magyar L, Gyeviki M (2008) Evaluation of native hybrids of prunus fruticosa Pall. as cherry interstocks. Acta Agric Serbica 13(25):41-45

Kárpáti Z (1944) Vizsgálatok a hazai Cerasus alnemzetségbe tartozó hazai Prunusokon. Bulletin of the Hungarian College for Horticulture and Vineculture, Budapest 10:66-80

Koller E, Fodor ZS, Orosz-Kovács Z, Hrotkó K, Róka K (1996) Cerasus fajok virágainak rovarvonzása. Lippay János tudományos ülésszak előadásainak és posztereinek összefoglalói, p 224

Krüssmann G (1978) Handbuch der Laubgehölze. 2. Aufl. Bd. III. Verlag Paul Parey

Liang C, Wan T, Xu S, Li B, Li X, Feng Y, Cai Y (2018) Molecular identification and genetic analysis of cherry cultivars using capillary electrophoresis with fluorescencelabeled SSR markers. 3 Biotech 8(1):16. https://doi.org/10. 1007/s13205-017-1036-7

Maas FM, Balkhoven-Baart J, van der Steeg PAH (2014) Evaluation of Krymsk ${ }^{\circledR} 5$ (VSL-2) and Krymsk ${ }^{\circledR} 6$ (LC-52) as rootstocks for sweet cherry 'Kordia'. Acta Hortic 1058:531-536. https://doi.org/10.17660/ActaHortic.2014. 1058.66

Macková L, Vít P, Ďurišová L, Eliáš P Jr, Urfus T (2017) Hybridization success is largely limited to homoploid Prunus hybrids: a multidisciplinary approach. Plant Syst Evol. https://doi.org/10.1007/s00606-016-1385-4

Magyar L, Hrotkó K (2008) Prunus cerasus and Prunus fruticosa as interstocks for sweet cherry trees. Acta Hortic 795:287-292. https://doi.org/10.1007/s00606-016-1385-4

Magyar L, Hrotkó K (2013) The effect of rootstock and spacing on the growth and yield of 'Kántorjánosi' sour cherry variety in intensive orchard. Acta Hortic 981:373-378. https://doi.org/10.17660/ActaHortic.2013.981.58

Mnejja M, Garcia J, Howad W, Badenes ML, Arús P (2004) Simple-sequence repeat (SSR) markers of Japanese plum (Prunus salicina Lindl.) are highly polymorphic and transferable to peach and almond. Mol Ecol Notes 4:163-166. https://doi.org/10.1111/j.1471-8286.2004. 00603.x

Olden EJ, Nybom N (1968) On the origin of Prunus cerasus L. Hereditas 59:327-345

Plock H (1973) Die Bedeutung der Prunus fruticosa Pall. als Zwergunterlage für Süss- und Sauerkirschen. Mitt Klosterneuburg 23:137-140

Rehder A (1990) Manual of cultivated trees and shrubs-hardy in North America. Dioscorides Press, Portland

Rozpara E, Grzyb ZS (2004) Frutana ${ }^{\circledR}$ - a new interstock for sweet cherry trees. Acta Hortic 658:247-250. https://doi. org/10.17660/ActaHortic.2004.658.34

Sonneveld T, Robbins TP, Boškovic R, Tobutt KR (2001) Cloning of six cherry self-incompatibility alleles and 
development of allele-specific PCR detection. Theor Appl Genet 102:1046-1055. https://doi.org/10.1007/ s001220000525

Surányi D (1982) A szenvedelmes kertész rácsudálkozásai. Magvető Kiadó Budapest, pp 170-178

Tavaud M, Zanetto A, David JL, Laigret F, Dirlewanger E (2004) Genetic relationships between diploid and allotetraploid cherry species (Prunus avium, Prunus $\times$ gondouinii and Prunus cerasus). Heredity 93(6):631

Terpó A (1974) Gyümölcstermő növényeink rendszertana és földrajza. In: Gyuró F (ed) A gyümölcstermesztés alapjai. Mezőgazdasági Kiadó, Budapest, pp 139-219

Westwood MN (1978) Mahaleb $\times$ Mazzard hybrid cherry stocks. Fruit Var J 32-39
Wojcicki JJ (1991a) Prunus $\times$ stacei (Rosaceae), a new spontaneous hybrid of $P$. fruticosa, $P$. cerasus and $P$. avium. Fragm Flor Geobot 35(1-2):139-142

Wojcicki JJ (1991b) Variability of Prunus fruticosa Pall. and the problem of anthropohybridization. Veröff Geobot Ist ETH Stiftung Rübel, Zürich 106:266-272

Xu Y, Ma RC, Xie H, Liu JT, Cao MQ (2004) Development of SSR markers for the phylogenetic analysis of almond trees from China and the Mediterranean region. Genome 47(6):1091-1104. https://doi.org/10.1139/g04-058

Publisher's Note Springer Nature remains neutral with regard to jurisdictional claims in published maps and institutional affiliations. 